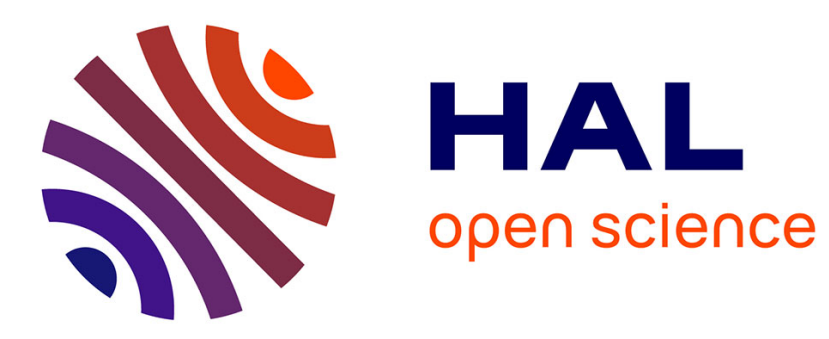

\title{
Impact of environmental conditions on the voltage profile of LV networks
}

Ferréol Binot, Trung Dung Le, Marc Petit

\section{To cite this version:}

Ferréol Binot, Trung Dung Le, Marc Petit. Impact of environmental conditions on the voltage profile of LV networks. 2019 IEEE PES Innovative Smart Grid Technologies Europe (ISGT-Europe), Sep 2019, Bucarest, Romania. 10.1109/ISGTEurope.2019.8905767 . hal-03021368

\section{HAL Id: hal-03021368 https://hal.science/hal-03021368}

Submitted on 24 Nov 2020

HAL is a multi-disciplinary open access archive for the deposit and dissemination of scientific research documents, whether they are published or not. The documents may come from teaching and research institutions in France or abroad, or from public or private research centers.
L'archive ouverte pluridisciplinaire HAL, est destinée au dépôt et à la diffusion de documents scientifiques de niveau recherche, publiés ou non, émanant des établissements d'enseignement et de recherche français ou étrangers, des laboratoires publics ou privés. 


\title{
Impact of environmental conditions on the voltage profile of LV networks
}

\author{
Ferréol BINOT, Trung Dung LE, Marc PETIT \\ GeePs | Group of electrical engineering - Paris, \\ CNRS, CentraleSupélec, Univ. Paris-Sud, Université Paris-Saclay, Sorbonne Université, \\ 3 \& 11 rue Joliot-Curie, Plateau de Moulon, 91192 Gif-sur-Yvette cedex, France \\ Ferreol.binot@centralesupelec.fr
}

\begin{abstract}
European distribution system operators (DSOs) should meet EN 50160 standard requirements on the whole network. With the development of distributed energy resources (DER), DSOs need to have a better insight of their low voltage (LV) networks. In this paper, we study the joint impact of external conditions (cable temperature, the ground resistivity and the ground resistances) on the voltage profile of three $L V$ networks in four cases. The results show that some voltage problems cannot be seen by using only usual values of those external conditions. By considering the values that are closer to the real conditions, the voltage analysis will be more accurate and in some cases, additional problems can be detected. To be sure that the EN 50160 standard is met, a global study of $\mathrm{LV}$ networks including the external conditions should be done.
\end{abstract}

Index Terms-Voltage profile, low voltage networks, temperature, ground resistivity, grounding resistance.

\section{INTRODUCTION}

In Europe, distribution system operators (DSOs) should meet the EN 50160 standard requirements. The main ones for low voltage $(\mathrm{LV})$ networks are that:

- Line-to-neutral voltages must be $95 \%$ of the time within the range of $\pm 10 \%$ of nominal voltage

- $\quad$ Line-to-neutral negative-sequence voltage must be $95 \%$ of the time less than $2 \%$ of the positivesequence voltage

This standard has been in use for several years. With the arrival of Smart Grids and fast development of distributed energy resources (DERs), more and more new components are connected to distribution networks. They are often single-phase components, thus potentially increase unbalance and reverse power flows. This increases the risk that DSOs no longer meet the standard [1]. To address future network constraints, network codes applied in Europe define the requirements enforced to significant grid users and DSOs [2]. Furthermore, new methods for LV network planning [3] and even for network real-time management [4] have been proposed. To be able to effectively implement these methods, DSOs should have a better knowledge of LV networks. In this paper, cable models and their impact to the voltage profile will be discussed. Obviously, the cable impedance matrix depends on environmental conditions. In LV network studies, reference values for external conditions (temperature, ground resistivity and earthing resistance) are commonly used and considered as constants [5]. However, these values are not well adapted for all networks. It could result in non-negligible errors in network analysis. The importance of studying the impact of their environment on LV cable models and voltage profiles has been highlighted in [6][8]. The summary of those studies are presented in Table I.

TABLE I

IMPACT OF EXTERNAL CONDITIONS IN THE LITERATURE

\begin{tabular}{|c|c|c|c|}
\hline Article & $\begin{array}{c}\text { External } \\
\text { condition }\end{array}$ & Affected parameter & Limits of the study \\
\hline$[6]$ & $\begin{array}{c}\text { Cable } \\
\text { temperature }\end{array}$ & $\begin{array}{c}\text { Sequence } \\
\text { impedance }\end{array}$ & $\begin{array}{c}\text { Not on line-to- } \\
\text { neutral voltage } \\
\text { Not with 4x4 matrix }\end{array}$ \\
\hline$[7]$ & $\begin{array}{c}\text { Ground } \\
\text { resistivity }\end{array}$ & $\begin{array}{c}\text { Positive sequence } \\
\text { impedance }\end{array}$ & $\begin{array}{c}\text { Only one external } \\
\text { condition }\end{array}$ \\
\hline$[8]$ & $\begin{array}{c}\text { Ground } \\
\text { resistances }\end{array}$ & $\begin{array}{c}\text { Line-to-neutral } \\
\text { voltage }\end{array}$ & \multicolumn{2}{c}{} \\
\hline
\end{tabular}

In [6] and [7], the impact of external conditions is only studied on sequence impedances and not on line-to-neutral voltages. It is difficult to isolate the impact of only one external factor by using the sequence impedances [9]. To highlight this impact, we propose to use the $4 \times 4$ impedance matrix. It gives a better insight of the impact of the external conditions and is able to model more accurately a LV cable. All the existing works are limited insofar as they focus on each condition separately. However, we argue that they should rather be studied jointly. To our knowledge, this work has not been done yet.

The main originality of this paper is to study the joint impact of external conditions on the line-to-neutral voltages. Moreover, our work enables DSOs to know which condition has a bigger impact on line-to-neutral voltages and to check that each network with its own particularities meets the EN 50160 standard requirements. The cable model is presented in Section II. Its dependencies to the external conditions are introduced in Section III. The test cases are described in Section IV. Results and discussions are shown in Sections V and VI.

\section{CABLE MODEL}

In this section, the cable model is described. The value of cable impedance is calculated for a LV cable used in many French networks. 


\section{A. Theoretical study}

In France, LV electric cables are composed of 4 conductors (Phases A, B, C and the neutral N). As a current can flow through the ground $(\mathrm{G})$, a fifth wire is considered for the cable model. This gives a $5 \times 5$ impedance matrix. However, the $5 \times 5$ impedance matrix is rarely used [10]. Usually, as the sum of the currents flowing in five wires is supposed to be zero, the $5 \times 5$ matrix is reduced to a $4 \times 4$ matrix by removing the ground wire.

$$
\left[\begin{array}{l}
\frac{V_{a n}^{k}}{V_{b n}^{k}}-\underline{V_{a n}^{l}} \\
\frac{V_{b n}^{l}}{\frac{V_{c n}^{k}}{V_{n g}^{k}}}-\underline{V_{c n}^{l}} \\
\underline{V_{n g}^{l}}
\end{array}\right]=\left[\begin{array}{llll}
\frac{Z_{a a}}{Z_{b a}} & \frac{Z_{a b}}{Z_{b b}} & \frac{Z_{a c}}{Z_{b b}} & \frac{Z_{a n}}{Z_{b n}} \\
\frac{Z_{c a}}{Z_{n a}} & \frac{\underline{Z_{c b}}}{Z_{n b}} & \frac{\underline{Z_{c n}}}{Z_{n c}} & \underline{\underline{Z_{n n}}}
\end{array}\right] *\left[\begin{array}{l}
\frac{I_{a}^{k l}}{I_{b}^{k l}} \\
\frac{I_{c}^{k l}}{\frac{I_{n}^{k l}}{I_{n}^{k l}}}
\end{array}\right]
$$

Ohm's law on a section of LV cable between $l$ and $k$ gives the equation (1) following the configuration given in Fig. 1. $R_{e}^{l}$ and $R_{e}^{k}$ are the earthing resistances of $l$ and $k$.

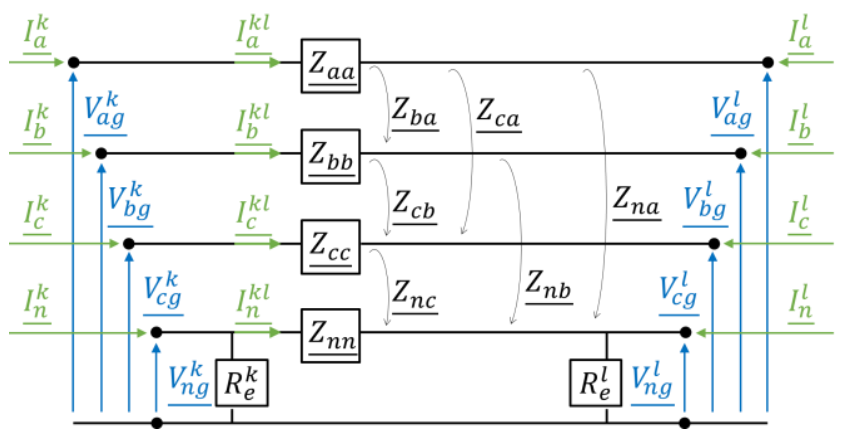

Figure 1. LV cable model

The ground wire impedance is included in the $4 \times 4$ matrix terms. We still define $D_{g}(\mathrm{~m})$, the ground radius and $r_{g}$ the ground per unit length resistance equals to $r_{g}=\frac{\mu_{0} \omega}{8}(\Omega / \mathrm{m})$. We also define $D_{i j}$ the distance between $i$ and $j$ conductors (including the ground conductor), $D_{i}(\mathrm{~m})$ the geometrical mean radius given by $D_{i}=e^{-1 / 4} R_{i}$ where $R_{i}$ is the physical radius $i$ of conductor, and the per unit length resistance $r_{i}=\frac{\rho_{i}}{\pi R^{2}}(\Omega / \mathrm{m})$.

The different terms of the $4 \times 4$ per-unit-length impedance matrix were calculated in [10]. Their expressions are as follows $(\Omega / \mathrm{m})$ :

$$
\begin{gathered}
z_{i i}=\left(r_{i}+r_{g}\right)+j \omega \frac{\mu_{0}}{2 \pi} * \ln \left(\frac{D_{i g} D_{g i}}{D_{i} D_{g}}\right) \\
z_{i j}=r_{g}+j \omega \frac{\mu_{0}}{2 \pi} * \ln \left(\frac{D_{i g} D_{g j}}{D_{i j} D_{g}}\right)
\end{gathered}
$$

Where $\mathrm{i}, \mathrm{j}=\mathrm{a}, \mathrm{b}, \mathrm{c}, \mathrm{n}$ and $\mathrm{i} \neq \mathrm{j}$.

As explained in [10], it is usually to consider $D_{g}=1 \mathrm{~m}$. In this case, [11] has determined (5).

$$
\frac{D_{i g} D_{g j}}{D_{g}}=\frac{658,9}{\sqrt{f / \rho_{\text {ground }}}}(\mathrm{m})
$$

Generally, the Kron reduction can be applied to the $4 \times 4$ matrix to remove the neutral conductor and obtain a $3 \times 3$ impedance matrix [10]. In the same way, the $3 \times 3$ matrix can be transformed in a diagonal $3 \times 3$ series impedance matrix via the method of symmetrical components [10]. But, neither the Kron reduction, nor the symmetrical components transform are well adapted for such networks because of highly unbalanced currents in LV networks and asymmetry in LV cables geometry [9]. Moreover, we can no longer determine the neutral-toground voltage if $3 \times 3$ impedance matrices were used. We thus choose to keep the $4 \times 4$ matrix in the following sections.

\section{B. Analytical and finite element values}

In this section, we consider the following LV cable which is used in French LV networks (Fig. 2b). The phases and neutral cross-sections are typically: 95/70, 150/95 and 240/115 $\mathrm{mm}^{2}$.

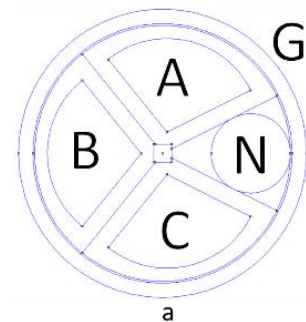

a

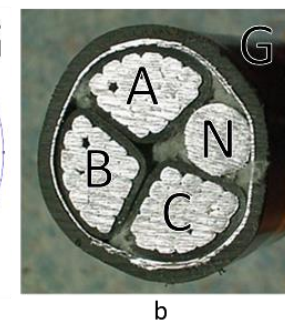

b

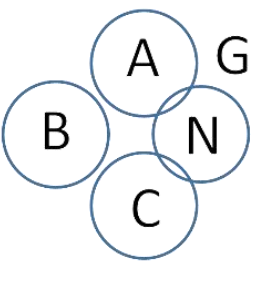

c
Figure 2. French 150/95 $\mathrm{mm}^{2}$ LV cable

a: Picture of studied cable

b: Finite element geometry

c: Analytical geometry

A reference case described in [11] is considered to model LV cables and to simulate LV networks. The parameters of the reference case are defined in Table II.

TABLE II

PARAMETERS FOR REFERENCE CASE

\begin{tabular}{|c|c|}
\hline Cable temperature, $T$ & $20^{\circ} \mathrm{C}$ \\
\hline Cable resistivity, $\rho_{i}$ & $3.068 \times 10^{-8} \Omega \mathrm{m}$ \\
\hline Ground resistivity, $\rho_{g}$ & $100 \Omega \mathrm{m}$ \\
\hline Study frequency, $f$ & $50 \mathrm{~Hz}$ \\
\hline
\end{tabular}

We also use this reference case to determine the $4 \times 4$ impedance matrix with analytical and finite element (FE) methods. Using analytical equations (3) and (4), the 4 x 4 matrix of $150 / 95 \mathrm{~mm}^{2}$ cable is $(\Omega / \mathrm{km})$ :

$$
\begin{aligned}
& z_{\text {analy }} \\
& =\left[\begin{array}{llll}
0.254+j 0.758 & 0.049+j 0.694 & 0.049+j 0.680 & 0.049+j 0.708 \\
0.049+j 0.694 & 0.254+j 0.758 & 0.049+j 0.694 & 0.049+j 0.679 \\
0.049+j 0.680 & 0.049+j 0.694 & 0.254+j 0.758 & 0.049+j 0.708 \\
0.049+j 0.708 & 0.049+j 0.679 & 0.049+j 0.708 & 0.299+j 0.764
\end{array}\right]
\end{aligned}
$$

For the FE method, we consider a cable length of $1000 \mathrm{~m}$ and an insulation resistivity of $10^{16} \Omega$-m modeled in the FE method magnetics (FEMM) software [10]. The mean error between analytical and FE methods is equal to $1.4 \%$. As results of both models are similar, we consider that the analytical model has good accuracy and can be used to model the cable. We choose to keep using this model in the following sections.

\section{DEPENDENCIES ON ENVIRONMENTAL CONDITIONS}

If the dependencies on environmental conditions are not considered in the previous section, this section analyses three types of external conditions: ground electrical resistivity, aluminum electrical resistivity and earthing resistances. 


\section{A. Dependency on ground electrical resistivity}

Considering (5), the imaginary parts of (3) and (4) are function of the ground resistivity. In the literature, various approaches of ground resistivity determination are proposed: geological approach [12], experimental measures [13] and manufacturers specifications [14]. They give different ranges of ground electrical resistivity. In [12], the authors describe the measurement of ground resistivity as a great method to determine soil characteristics. In that way, ground resistivity is very influenced by the soil type and varies from 1 to 10000 Ohm-m (fig. 3).

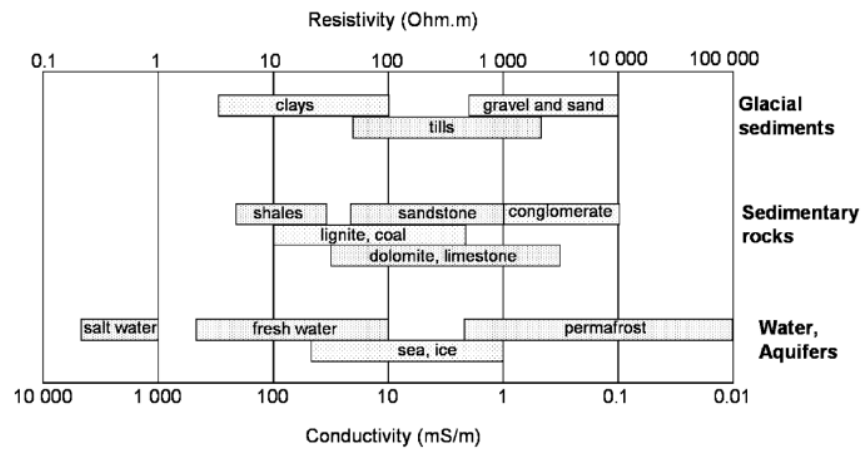

Figure 3 Typical ranges of electrical resistivity of earth materials [12]

Unfortunately, ground resistivity is also influenced by ground temperature, moisture, water conductivity and local heterogeneities (e.g. conductive pipes in the neighboring soil) [12]. It is difficult to model all these conditions to obtain a global probability density function. Moreover, the geological composition of soil is not uniform within a country.

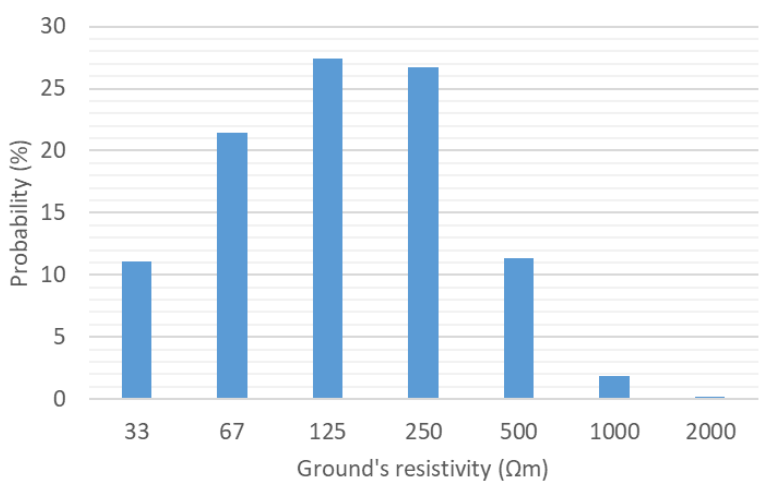

Figure 4 Probability density function of ground resistivity

Experimental measurements of ground resistivity have been conducted in the USA [13]. These measurements enabled us to draw the probability density function of ground resistivity reproduced in fig. 4 . The main value of ground resistivity is around $150 \Omega / \mathrm{m}$ which is higher than the reference value. Finally, a manufacturer provides in Table III the ground electrical resistivity of more familiarly named soils [14].

\section{B. Dependancy on earthing resistances}

Earthing resistances do not have an impact on equations (3) and (4). However, the resistances impact the neutral-to-ground and line-to-ground voltages [8]. These resistances are function of the soil type and the earthing techniques. Common values of earthing resistance are shown in Table III.

TABLE III

EARTHING RESISTANCE OF DIFFERENT SOILS

\begin{tabular}{|c|c|c|c|c|}
\hline \multirow{2}{*}{ Type of soil } & \multirow{2}{*}{$\begin{array}{c}\text { Soil } \\
\text { resistivity }\end{array}$} & \multicolumn{3}{|c|}{ Earthing resistance $(\mathbf{\Omega})$} \\
\cline { 3 - 5 } & $(\mathbf{\Omega}-\mathbf{m})$ & $\mathbf{3}(\boldsymbol{m})$ & $\mathbf{6}(\boldsymbol{m})$ & $\mathbf{1 0}(\boldsymbol{m})$ \\
\cline { 3 - 5 } & 30 & 10 & 5 & 3 \\
\hline Very moist soil & 100 & 33 & 17 & 10 \\
\hline Farming soil & 150 & 50 & 25 & 15 \\
\hline Sandy clay soil & 500 & 160 & 80 & 48 \\
\hline Moist gravel & 1000 & 330 & 165 & 100 \\
\hline Dry gravel & 30,000 & 1000 & 500 & 300 \\
\hline Stoney soil & &
\end{tabular}

C. Dependency on aluminum electrical resistivity

This last dependency variation is better known. In fact, the real parts of (3) and (4) are a linear function of the aluminum electrical resistivity, i.e. the main cable material. Aluminum resistivity is mainly temperature dependent:

$$
\rho_{\text {alu }}(T)=\rho_{0}\left[1+\alpha *\left(T-T_{0}\right)\right]
$$

Where $\alpha=3,63 \times 10^{-3} K^{-1}$ and $\rho_{0}=2,86 \times 10^{-8} \Omega m$ at $T_{0}=273 \mathrm{~K}$.

The cable temperature may vary between 0 and $100^{\circ} \mathrm{C}$ [4]. Intuitively, a part of this temperature variation results from Joule effect. As described in [15], pavement also has an impact on the ground and the cable temperatures. This impact is not linear and is function of the network layout. We then present a time dependent thermal FE study in the following section.

\section{Methodology AND Test CASES}

The proportion of LV underground cables is significant in Europe. Impact of external factors described in section III cannot be directly measured. In this section, we present the method developed to analyze jointly these external effects on a $4 \times 4$ matrix and on a line-to-neutral voltage.

\section{A. Global approach}

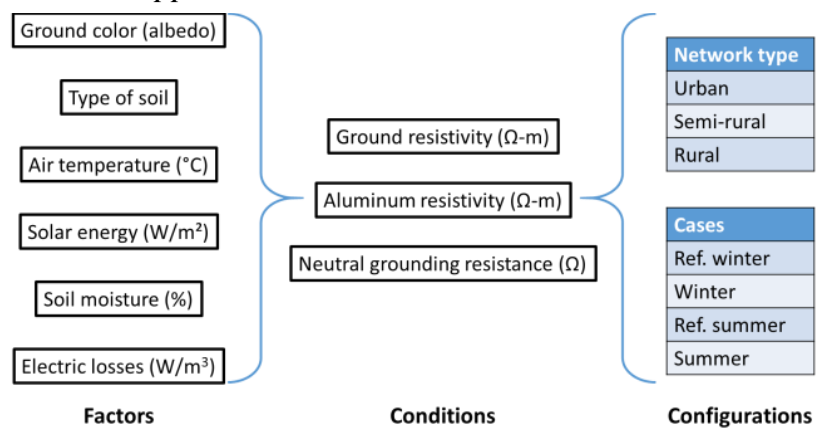

Figure 5 Factors, conditions and configurations for sensibility analysis

The three external conditions discussed before are also influenced by other external factors such as soil surface color, soil type, air temperature, solar energy, soil moisture and electric losses, as shows Fig. 5. The probability density function of all these factors is difficult to determine and all these factors are interdependent. Therefore, we consider three types of network (urban, semi-rural and rural) and simulate each of them in four types of cases (reference winter, winter, reference summer and summer). 


\section{B. Studied networks}

Parameters of the studied networks (urban, semi-rural and rural) are presented in Table IV.

TABLE IV

LV NETWORKS TYPES PARAMETERS

\begin{tabular}{|c|c|c|c|}
\hline Networks types & Urban & Semi-rural & Rural \\
\hline Nominal power of transformer & $400 \mathrm{kVA}$ & $250 \mathrm{kVA}$ & $100 \mathrm{kVA}$ \\
\hline Consumers number & 148 & 31 & 4 \\
\hline Annual mean consumption & $65.7 \mathrm{~kW}$ & $24.3 \mathrm{~kW}$ & $5 \mathrm{~kW}$ \\
\hline Producers number & 9 & 0 & 1 \\
\hline DER contract power & $105.4 \mathrm{~kW}$ & $0 \mathrm{~kW}$ & $18 \mathrm{~kW}$ \\
\hline Network length & $4.0 \mathrm{~km}$ & $4.0 \mathrm{~km}$ & $1.0 \mathrm{~km}$ \\
\hline
\end{tabular}

These LV networks are part of the distribution dataset used in the CGMES 2.4.1 interoperability tests performed in 2016 [16]. For the ground electrical resistivity, we consider that urban, semi-rural and rural ground are respectively sandy clay soil, moist gravel and very moist soil. We also suppose that the ground electrode is 3 meters in depth and the neutral wire is not grounded at every node.

\section{Studied cases}

We consider four type of cases (reference winter, winter, reference summer and summer) to illustrate the impact of the external factors. Table $\mathrm{V}$ gives the values of external conditions used in different configurations. Consumption and production profile are specified using data from [17] and [18]: for the 2 winter cases, we consider the most critical moments of winter, i.e. the 24 highest successive consumption values in winter (winter profile), and for the 2 summer cases, we consider the most critical moments of summer, i.e. the 24 highest production values in summer (summer profile). The calculated temperature in the more realistic cases are from a COMSOL time dependent thermal model.

TABLE V

VALUES OF EXTERNAL CONDITIONS IN DIFFERENT CONFIGURATIONS

\begin{tabular}{|c|c|c|c|}
\hline & Urban & Semi-rural & Rural \\
\hline Ref. winter & $\begin{array}{c}R_{e}=1 \Omega \\
T_{\text {cable }}=20^{\circ} \mathrm{C} \\
\rho_{g}=100 \Omega m \\
\text { winter profile }\end{array}$ & $\begin{array}{c}R_{e}=1 \Omega \\
T_{\text {cable }}=20^{\circ} \mathrm{C} \\
\rho_{g}=100 \Omega \mathrm{m} \\
\text { winter profile }\end{array}$ & $\begin{array}{c}R_{e}=1 \Omega \\
T_{\text {cable }}=20^{\circ} \mathrm{C} \\
\rho_{g}=100 \Omega \mathrm{m} \\
\text { winter profile }\end{array}$ \\
\hline Winter & $\begin{array}{c}R_{e}=1 \Omega \\
T_{\text {cable }}=35^{\circ} \mathrm{C} \\
\rho_{g}=150 \Omega m \\
\text { winter profile }\end{array}$ & $\begin{array}{c}R_{e}=1 \Omega \\
T_{\text {cable }}=25^{\circ} \mathrm{C} \\
\rho_{g}=500 \Omega \mathrm{m} \\
\text { winter profile }\end{array}$ & $\begin{array}{c}R_{e}=1 \Omega \\
T_{\text {cable }}=15^{\circ} \mathrm{C} \\
\rho_{g}=30 \Omega \mathrm{m} \\
\text { winter profile }\end{array}$ \\
\hline Ref. summer & $\begin{array}{c}R_{e}=1 \Omega \\
T_{\text {cable }}=20^{\circ} \mathrm{C} \\
\rho_{g}=100 \Omega \mathrm{m} \\
\text { summer profile }\end{array}$ & $\begin{array}{c}R_{e}=1 \Omega \\
T_{\text {cable }}=20^{\circ} \mathrm{C} \\
\rho_{g}=100 \Omega \mathrm{m} \\
\text { summer profile }\end{array}$ & $\begin{array}{c}R_{e}=1 \Omega \\
T_{\text {cable }}=20^{\circ} \mathrm{C} \\
\rho_{g}=100 \Omega \mathrm{m} \\
\text { summer profile }\end{array}$ \\
\hline Summer & $\begin{array}{c}R_{e}=50 \Omega \\
T_{\text {cable }}=65^{\circ} \mathrm{C} \\
\rho_{g}=150 \Omega \mathrm{m} \\
\text { summer profile }\end{array}$ & $\begin{array}{c}R_{e}=160 \Omega \\
T_{\text {cable }}=50^{\circ} \mathrm{C} \\
\rho_{g}=500 \Omega \mathrm{m} \\
\text { summer profile }\end{array}$ & $\begin{array}{c}R_{e}=10 \Omega \\
T_{\text {cable }}=35^{\circ} \mathrm{C} \\
\rho_{g}=30 \Omega \mathrm{m} \\
\text { summer profile }\end{array}$ \\
\hline
\end{tabular}

\section{RESULTS}

The load flow is computed by EPRI's OpenDSS [19] on the three test networks presented previously. We analyze the impact of external conditions on voltage limits and voltage unbalance of the 24 summer moments and 24 winter moments.

\section{A. Voltage limits}

A voltage problem occurs when a line-to-neutral voltage exceeds the range of $\pm 10 \%$, Fig. 6 and 7 show the ratio of voltage problem $\tau_{v}$ defined in (7).

$$
\tau_{v}=\frac{N_{\text {pbr }}}{N_{\text {node }} * N_{\text {phase }} * N_{\text {moment }}}
$$

Where $N_{p b r}$ : the number of voltage problems, $N_{\text {node }}$ : number of nodes, $N_{\text {phase }}$ : the number of phases and $N_{\text {moment }}$ : the number of studied moments.

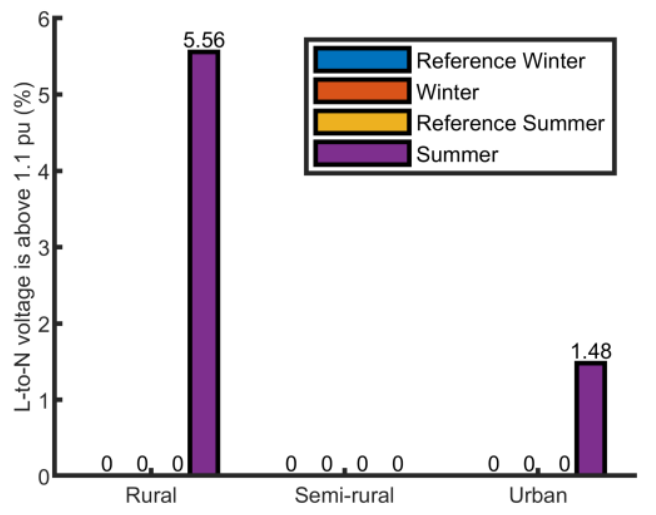

Figure 6 Percentage of upper voltage problem

In Fig. 6, the upper limit of the standard is exceeded only in summer. Production units are only connected to the urban and rural networks. Hence, the presence of producers increases the risk to exceed the EN 50160 standard requirements in summer. The increase is higher in the rural than in the urban network.

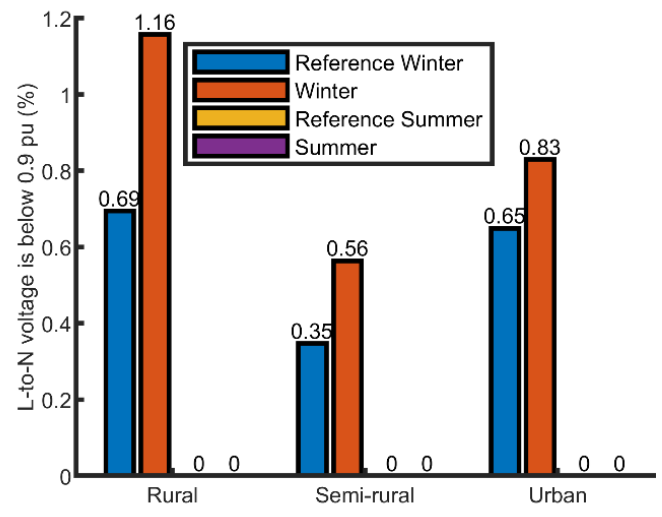

Figure 7 Percentage of lower voltage problem

In Fig. 7, the lower limit is never reached in summer. In all networks, the number of cases where line-to-neutral voltages are below 0.9 pu rises from the reference winter case to the winter case. The increase is similar in the rural and in the semirural networks but higher than in the urban network.

\section{B. Voltage unbalance}

A voltage unbalance problem occurs when the negativesequence voltage is above $2 \%$ of the positive-sequence voltage. Fig. 8 shows the ratio of voltage problem $\tau_{v}$ defined in (7). The impact of external conditions is visible in the urban network, where the number of critical situations rises from $1.33 \%$ to $1.84 \%$ in winter. In the other situations, the impact is negligible. 


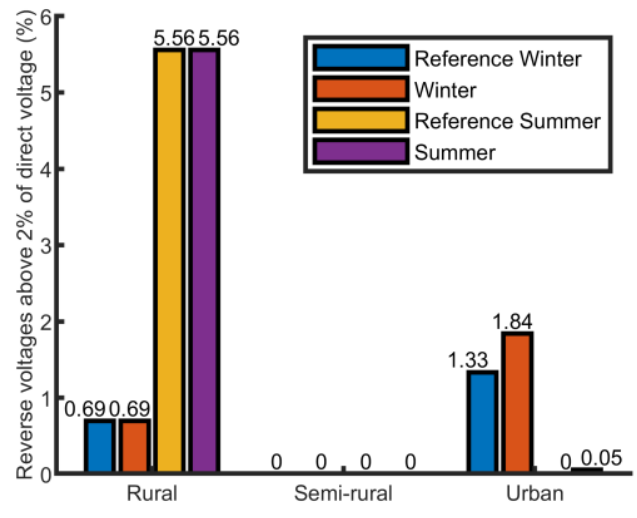

Figure 8 Percentage of voltage unbalance problem

\section{Results analysis}

We also study the impact of temperature alone on the $4 \times 4$ impedance matrix and on the voltage profile. Only the real part of $\underline{z_{a a}}$ is influenced by the cable temperature [10]. Table VI shows the proportionality of these quantities in regards to the temperature in the rural network. Similar results are obtained for the two other networks.

TABLE VI

IMPACT OF CABLE TEMPERATURE ON PER-UNIT LENGTH RESISTANCE AND AVERAGE VOLTAGE

\begin{tabular}{|c|c|c|c|}
\hline & $\mathbf{2 0}^{\circ} \boldsymbol{C}$ & $\mathbf{4 0}^{\circ} \boldsymbol{C}$ & $\mathbf{1 0 0}^{\circ} \boldsymbol{C}$ \\
\hline Variation of $\boldsymbol{R e}\left(\underline{z}_{\boldsymbol{a a}}\right)$ & Default & $+6.07 \%$ & $+24.33 \%$ \\
\hline Variation of average voltage & Default & $+0.15 \%$ & $+0.62 \%$ \\
\hline
\end{tabular}

The impact of external conditions is easily observable by using the $4 \times 4$ impedance matrix [10] instead of using the diagonal $3 \times 3$ series impedance matrix [6], [7]. However, the impact of external conditions on voltage problems depends also on the network type. Rural network feeders are often longer than urban network ones and their cable cross-sections are often smaller. Hence, line-to-neutral voltages of rural networks are usually closer to the EN 50160 standard voltage limits than urban networks. Thus the impedance matrix of rural networks should be known with higher precision than that of urban networks.

\section{CONCLUSION}

In this paper, the impact of three external conditions on the voltage profile of three LV networks is jointly studied. For each network, four cases are considered: winter, reference winter, summer, and reference summer. The results show that some voltage problems cannot be seen by using only usual values of those external conditions. By considering the values that are closer to the real conditions, the cable model parameters can be more accurately estimated. As a result, the voltage analysis will be more accurate and in some cases, additional problems can be detected. The authors recommend the use of $4 \times 4$ impedance matrix with an earthing resistance instead of the sequence impedances to describe more precisely LV networks. Besides, results show also that rural and some semi-rural networks are more prone to voltage problems than urban networks. To be sure that the EN50160 standard is met, a global study of LV networks including the external conditions should be done. In practice, it is difficult to determine the exact value of external conditions for each network or each cable section. Then a LV parameter estimator could be an interesting solution to deal with this problem.

\section{REFERENCES}

[1] Y. Liu et al., "Distribution network voltage control by active power/reactive power injection from PV inverters," in 2018 13th IEEE Conference on Industrial Electronics and Applications (ICIEA), 2018, pp. 543-547.

[2] European Commission, "Electricity network codes and guidelines," Energy - European Commission, 23-Oct-2014. [Online]. Available: https://ec.europa.eu/energy/en/topics/markets-and-

consumers/wholesale-market/electricity-network-codes. [Accessed: 08Apr-2019].

[3] D. F. Frame, G. W. Ault, and S. Huang, "The uncertainties of probabilistic LV network analysis," in 2012 IEEE Power and Energy Society General Meeting, 2012, pp. 1-8.

[4] A. Angioni, J. Shang, F. Ponci, and A. Monti, "Real-Time Monitoring of Distribution System Based on State Estimation," IEEE Transactions on Instrumentation and Measurement, vol. 65, no. 10, pp. 2234-2243, Oct. 2016.

[5] W. H. Kersting, "A three-phase unbalanced line model with grounded neutrals through a resistance," in 2008 IEEE Power and Energy Society General Meeting - Conversion and Delivery of Electrical Energy in the 21st Century, 2008, pp. 1-2.

[6] A. Urquhart, "Accuracy of Low Voltage Electricity Distribution Network Modelling," PhD thesis, Loughborough University, 2016.

[7] H. Keshtkar, S. K. Solanki, and J. M. Solanki, "Improving the Accuracy of Impedance Calculation for Distribution Power System," IEEE Transactions on Power Delivery, vol. 29, no. 2, pp. 570-579, Apr. 2014.

[8] F. Olivier, R. Fonteneau, and D. Ernst, "Modelling of three-phase fourwire low-voltage cables taking into account the neutral connection to the earth," Jun. 2018.

[9] L. Moreno-Díaz, E. Romero-Ramos, A. Gómez-Expósito, E. CorderoHerrera, J. R. Rivero, and J. S. Cifuentes, "Accuracy of Electrical Feeder Models for Distribution Systems Analysis," in 2018 International Conference on Smart Energy Systems and Technologies (SEST), 2018, pp. 1-6.

[10] F. Binot, T. D. Le, and M. Petit, "Modélisation de l'impédance des câbles : Étude de sensibilité et impact sur le réseau BT," in Symposium de Génie Electrique, 2018.

[11] A. J. Urquhart and M. Thomson, "Series impedance of distribution cables with sector-shaped conductors," Transmission Distribution IET Generation, vol. 9, no. 16, pp. 2679-2685, 2015.

[12] A. Samouëlian, I. Cousin, A. Tabbagh, A. Bruand, and G. Richard, "Electrical resistivity survey in soil science: a review," Soil and Tillage Research, vol. 83, no. 2, pp. 173-193, Sep. 2005.

[13] Rural Electrification Administration, "REA BULLETIN," 1751F-802, Dec. 1994.

[14] FLUKE, "Earth Grounding Resistance." [Online]. Available: https://dam-assets.fluke.com/s3fspublic/4346628_0000_ENG_C_W.PDF. [Accessed: 13-Nov-2018].

[15] H. Li, J. T. Harvey, T. J. Holland, and M. Kayhanian, "The use of reflective and permeable pavements as a potential practice for heat island mitigation and stormwater management," Environ. Res. Lett., vol. 8, no. 1, p. 015023, 2013.

[16] Entsoe, "INTEROPERABILITY TEST "CIM FOR SYSTEM DEVELOPMENT AND OPERATIONS' 2016,” European Network of Tranmission System Operators for Electricity, Jul. 2016.

[17] Commission for Energy Regulation, "Results of electricity cost-benefit analysis, customer behavior trials and technology trials. Technical report.," Dublin, 2011.

[18] Commission for Energy Regulation, "Electricity smart metering customer behavior trials findings report. Technical Report.," Dublin, 2011.

[19] "OpenDSS," SourceForge. [Online]. Available: https://sourceforge.net/projects/electricdss/. [Accessed: 03-Dec-2018]. 